\title{
How Promotional Advertisements Can Change the Buying Behavior of Children
}

\author{
Muhammad Irfan Akram¹, Sheikh Aftab Ahmad², Ahsan Ul Haq ${ }^{3}$ \\ ${ }^{1}$ Government College University, Faisalabad, Pakistan \\ ${ }^{2}$ Department of Economics and Finance, University of Hail, Saudi Arabia \\ ${ }^{3}$ Riphah International University, Faisalabad, Pakistan \\ Irfan99438101@gmail.com, aftab_ahmad@hotmail.co.uk, ahsanahmad857@gmail.com
}

\begin{abstract}
This study aims to highlight the impact of promotional advertising on children's buying behavior. Promotions are tools that maximize the sales of any organization. Retailers or manufacturers apply this tool to invite consumers to buy more products. The proposed study aims to focus the advertising impact on child purchases in the Pakistani capital. It is convenient to sample 500 respondents and collect data with the help of the questionnaire. The results show that there is a negligible correlation between the purchase behavior and coupons. On the contrary, buying one-to-one free, the physical environment impacts significantly on the purchase behavior. The proposed research helps marketers recognize most effective promotional ads that can significantly affect a child's buying behavior.
\end{abstract}

Keywords: Promotions, coupons, children buying behavior, discount, free sampling.

\section{Introduction}

A promotion or advertisement is a basic tool used by a retailer or manufacturer to invite customers to purchase additional products. The output results one get from the promotion are high income, new customer invitations and more sales growth. Growth leads to more customer acquisition and increased mediation or efficiency, as well as supplier cooperation. When a trader conducts very little cognitive activity, the purchase conditions are normal. Of course, it is difficult to encourage changes to the brand or increase the purchase of equipment. Increasing interest in marketing campaigns has led to increased research in this area. For example, due to increased sales, there is a large body of literature on customer response. Increased interest in the use of key marketing promotions has led to unprecedented growth in research in this area (MOULAND, 2002). Promotional sales have a comprehensive promotional tool designed to create easy-to-use conversations (Gilbert \& Jackaria, 2002). They said that sales promotion tools are encouraging consumers to think and at the same time evaluate brands and buying opportunities. Therefore, advertising tools and advertising strategies are used by traders to be able to know the initial opportunities of their customers and to increase their sales. This fact shows that many consumers can easily be squeezed when they recognize the term "sales promotion." In addition to reducing discounts or promotions of credit cards offered by retailers and other marketing tools such as free purchases and payments received without indicating that they make consumers buy additional advertising strategies used by vendors to attract customers and increase sales (Gilbert \& Jackaria, 2002).

Previous research has shown that creative advertising and price information affect consumers' perceptions of value and readiness to buy (Das, 1992). The aim of this study to highlight the impact of different instruments on consumer purchasing behavior, therefore learning tools are very important for recognizing the most powerful tools to compete with their competitors. The purpose of this study is to carefully review the client's love of the advertising tools. Using this information, retailers and retailers can plan their resources for the most profitable. The purpose of this study is to study the bias of the media consumption device, and retailers will be able to understand buyers' behavior to use the most effective and successful customer engagement techniques. Ads usually include discount free coupons and a guarantee package, but in this study, we are going discuss the impact of the discount voucher and stocks on buyer behavior. The natural environment is a factor that affects customer behavior when purchasing. These advertising techniques influence the buyer's behavior when purchasing goods. Previous studies have shown that these factors have a significant impact on purchasing behavior. The effects of these instruments vary from country to country. So our findings can lead to different results from previous studies (Sinha \& Smith, 2000). There are several types of short-term equipment that are used to make buyers and / or dealers accelerate purchases or increase sales volumes. Sales promotion is an integral part of the commercial mix and marketing tool. The result of this sale is the promotion of the use of high-quality stocks, attracting new customers and increasing sales. 


\section{Literature Review}

Advertisement is a tool that is used by retailers or manufacturers to attract customers to buy multiple services or products or trials. Sinha and Smith (2000), have pointed out that rising sales may be beneficial to users who plan to advertise at a reasonable price. Many of them use trademark change so they can buy big deal and create their own smart products and these users have been popularized. These users have tested new products or services that are installed. For example, lowering prices within a deadline to attract new customers is called "price promotions." Promoting sales means that the manufacturer uses any activity to provide retail (wholesale or wholesale) retail networks and to enable customers to buy the brand and increase their sales. Sales promotion refers to a variety of incentives and methods to create immediate sales efficiency (Totten \& Block, 1994). Sales are increased by $75 \%$ of total market budget as stated by the packaging stats (Neslin, 2013). Compared to the traditional sales increases, improving online sales of goods has almost similar goals, goals and actions even in a particular environment. Promoting online sales is an activity that uses any incentives to target targeted users and increase their goal of purchasing specific products / services. Early market research both, theory and experiment, focuses on how sales have influenced consumer behavior, especially their purchasing decisions.

Most studies come to the conclusion that sales promotion can have serious consequences for behavior of users and purchasing decisions, although the effects of different compounds differ. Like retailers on the Internet, there are some advertising tools such as logos, pop-ups, pop-ups, emails, and hyperlinks to websites. These types of ads have a positive impact on online purchases (Thota, Song, \& Larsen, 2010). The terms of coupon apply to the customer who is eligible for a subsidy for a normal product (Thota et al., 2010). Coupons are actually the certificates or vouchers that help consumers reduce prices for specific products (Cuizon, 2009). Discounts or reduced prices are limited and the coupon is displayed when the customer purchases the product. According to Thota et al. (2010) are easy to understand by customers and can be very useful for buying. Cards are a way for manufacturers to communicate with customers and can be used as converters. Park, Kim, Funches, and Foxx (2012), stated that for several years, as a way to show consumers how to reduce their costs and build brand awareness and loyalty for that purpose, they are being used as an important advertising tool. Indeed, the party changing the brand and brand trade suggests that consumers are influenced by the concessions announced in the party. It was noticed in a previous research that even after six months of having one of the stated proposals, the customer was more likely (even up to two to five times) to buy and use the trademark.

Customers do not get a card. Customers who received the card also had twice to show that they will buy a brand in the future. In the survey, new customers of three new credit card programs have shown that brands that accelerate sales profits by expanding and buying unsuccessful coupons. They also said that coupon promotion was among the less used and incomparable market instruments (MOULAND, 2002). One Free Get Free is a sales promotion approach that offers customers additional products at a normal price with improved package improvements. Customers can easily influence purchases of products as they do not receive additional costs and should be highly valued by consumers (Kim, 2002). Parks and schools say that large packaging and advertising of appropriate products increase the attractiveness of the program. When additional production is loaded without added value, consumers can persuade them to buy the product if the customer believes the money can be retained under the agreement. Bonus packages encourage consumers to buy products (Gilbert \& Jackaria, 2002). Bonus packages are preferred by manufacturers or manufacturers because they need to increase product testing and store stores. According to scientists, advertising technology will have tremendous advantages for the manufacturer as it should help retailers clean up warehouses when prices are high (Bakewell \& Mitchell, 2003).

\section{Methodology}

Descriptive type of research is used in this study. It can be explained in a specific situation, telling something or some obvious fact. Studies that explain the status quo rather than interpretation and judgment are descriptive. The core goal of descriptive research is the establishment of an accurate study of developmental hypotheses that project current state. Pilot studies have been completed prior to conducting actual research. The core study of the pilot study was that the sample of 500 respondents with computational reliability was 
selected from different shopping centers in Islamabad. The questionnaire was used as a research tool for current research. The questionnaire consists of two main sections. The initial part contains the previous background of the respondent who is currently responding the questionnaire; the second part is the awareness about various promotional tools and the purchasing behavior of that person. In the first part, each person answering the questionnaire is asked to provide his/her current age, gender, education, monthly income, and status. Five items were selected in order to measure each variable. Each variable is calculated based on five items. To calculate the buyer purchase behavior, total eight items are used. Buy one get one free, coupons and an environmental factor, the physical environment has been tested. In this study, 5 points likert scale was used, 1 (strongly agree), and 5 (strongly disagree).

\section{Results and Discussion}

Core purpose of this section is to analyze and interpret data relevant to research questions in the survey. Univariate analysis explores each variable in the data set separately. It looks at the range and central tendency of the values at the same time. It describes each variable response mode on its own. It represents each variable by itself. The univariate descriptive statistics describe the individual variables. The descriptive analysis is based on the personal data of the respondents in the table below:

Table 1: Percentage-Wise Average Distribution of the Respondents in Correspond the Gender

\begin{tabular}{lll}
\hline Gender & Freq. & Percentage \\
\hline Female & 284 & 57 \\
Male & 216 & 43 \\
Total & $\mathbf{5 0 0}$ & $\mathbf{1 0 0}$ \\
\hline
\end{tabular}

Table 1 illustrates that majority of the respondents i.e. 43 percent were female, while 57 percent of the respondents were male.

Table 2: Percentage-Wise Spread of Volunteers With Respect to their Age

\begin{tabular}{lll}
\hline Age & Freq. & Percentage \\
\hline $5-8$ & 81 & 16.2 \\
$9-12$ & 185 & 37 \\
$13-18$ & 234 & 46.8 \\
Total & $\mathbf{5 0 0}$ & $\mathbf{1 0 0}$ \\
\hline
\end{tabular}

Table 2 represents that $16.2 \%$ of respondents falls between the age group of 5-8, $37 \%$ were belonging to 912 , while $46.8 \%$ of the respondents fit in the age group of $13-18$.

Table 3: Percentage Distribution of the Respondents With Respect to Educational Status

\begin{tabular}{lll}
\hline Educational Status & Frequency & Percentage \\
\hline $1-3$ class & 80 & 16 \\
$4-7$ class & 186 & 37.2 \\
8-10\& HSSC & 234 & 46.8 \\
Total & $\mathbf{5 0 0}$ & $\mathbf{1 0 0 . 0}$ \\
\hline
\end{tabular}

Table 3 points out that 16 percent of the respondents from 1-3 class, 37.2 percent had up to 4-7 level of education, most of the respondents 46.8 percent had 8-10\& HSSC.

Table 4: Percentage Distribution of Respondents According to their Household Income

\begin{tabular}{lll}
\hline Income (Rs.) & Frequency & Percentage \\
\hline Up to 35000 & 153 & 30.6 \\
$35001-45000$ & 109 & 21.8 \\
$45001-55000$ & 94 & 18.8 \\
55001 or above & 141 & 28.2 \\
Total & $\mathbf{5 0 0}$ & $\mathbf{1 0 0}$ \\
\hline
\end{tabular}

Table 4 above describes the household income of respondents for all resources. The table shows that $36.7 \%$ of respondents reached the rupee. 35,000 households have monthly income, and $21.8 \%$ have rupees. 
Household income from all sources is $35001-45000$, of which $18.8 \%$ is Rs. $45001-55000,28.2 \%$ have rupees more than 55001 monthly incomes from all aspects.

Table 5: Distribution of Variables With Respect to their Mean and Standard Deviation

\begin{tabular}{lll}
\hline Variables & Mean & Standard Deviation \\
\hline Education & 2.7333 & 1.03934 \\
Gender & 1.3167 & 0.46910 \\
Income & 2.5833 & 1.51032 \\
Age & 1.4833 & 0.65073 \\
\hline
\end{tabular}

Table 5 depicts the relation of standard deviation and mean with respect to the average distribution of the variables. The values of the mean and standard deviation describe the mean of the variable being greater than its standard deviation. It highlights that the data is close to its average, so we can say that there is a difference between the data, so the attributes are good and the error probability is very low

Inferential Statistics: In this study, multi-line growth rates were made to examine the effects of the independent variables on the response rate. Regression modelling is an important method of analysis to identify causal links between variables and explanatory variables. This model is used to study the effects of more than two variables on the response variable. However, the determinants of the life assurance community behaviour are analysed by the regression model. Linear relationships are analysed by graphs, and the correct lines indicate that the model can be applied. The coefficient of this variable has a positive sign and the value of 0.288 has a strong significant correlation at the 1 and $5 \%$ significance levels. The regression analysis is performed using the regression method step by step. This procedure only includes those variables whose p-values of their regression coefficient are less than or equal to 0.05 . As an alternative, this procedure only includes those variables in the sample that have a significant impact on the variable based on $1 \%$ or $5 \%$. The entire regression analysis is performed using the Social Science Statistics (SPSS) version 17.0. The results of the gradual decrease regression analysis show that the above variables have a significant impact on the response threshold.

Table 6: Influence of Various Independent Variables on Dependent Variable: A Multiple Linear Regression Model

\begin{tabular}{llllll}
\hline Variables & $\begin{array}{l}\text { Unstandardized } \\
\text { Coefficient } \\
\text { B }\end{array}$ & Std. Error & $\begin{array}{l}\text { Standardized } \\
\text { coefficient } \\
\text { Beta }\end{array}$ & T & Sig. \\
\hline Constant & 1.053 & 0.178 & & 4.684 & $0.000^{* *}$ \\
Sale Promotion & 0.540 & 0.085 & 0.288 & 3.373 & $0.000^{* *}$ \\
B1 G1 & 0.286 & 0.050 & 0.312 & 4.659 & $0.000^{* *}$ \\
Coupons & 0.133 & 0.072 & 0.081 & 1.738 & $0.003^{*}$ \\
\hline
\end{tabular}

Dependent Variable: Consumer Behavior

$\mathbf{R}^{2}=0.87 \quad$ F-value $=22.45$ Sig. $=0.000^{* *}$

The value of R-Square is 0.87 . This suggests that $87 \%$ of customer satisfaction is explained by three variables, such as promotional B1 G1 and coupons. The overall meaning of the model can also be judged by the F test. The $\mathrm{F}$ value is 22.45 , which is significantly below the significant level of $5 \%$. This also shows that the model is very important. The coefficient of this variable has a positive value with a value of 0.312 and a high significance at the $5 \%$ significance level. Sales promotions or the environment have a major impact on consumer buying behavior. Therefore, the results of this study indicate that the promotion and environment of retail stores are also an important factor affecting consumers' willingness to purchase, and have a strong and significant relationship with consumers' purchasing behavior. The coefficient of this variable has a positive sign and the value of 0.288 has a strong significant correlation at the 1 and $5 \%$ significance levels. It illustrates the strong positive impact a person has on consumer buying behavior. It pointed out that most of the respondents were affected by such proposals, which increased the sales of the products. It shows that useful product advertisements appeal to customers. The coefficient of this variable has a positive sign and the value of 0.143 is significant at the level of significance of $5 \%$. It points out that promotional tools like the 
coupons and sales options used by marketing companies are very important. These tools draw the attention of the customer if the tool's performance is higher than the customer's purchase level.

\section{Conclusion}

Advertising promotes the important role of merchants and retailers in marketing programs. By using promotional devices, promotional sales can generate more revenue and sales. Traders use many marketing techniques to give consumers more incentive to buy their products and then advertise in a classic way. The study, supported by research by Cuizon (2009), said that sales growth is not only effective in obtaining shortterm sales, it is also a very effective tool compared to marketing communications, including advertising. A review of this study is that we have a positive attitude towards a positive buying behavior market. The survey confirms that buyers' attitudes can be promoted through various types, including promotional techniques such as free coupons and the body. In addition, the structure provides a new perspective on how different customers respond to the various multimedia devices offered by the market and their impact on consumer buying behavior, which may be a key market for your use of perfect strategies, promotions and advertising tools.

\section{References}

Bakewell, C. \& Mitchell, V. W. (2003). Generation Y female consumer decision-making styles. International Journal of Retail \& Distribution Management, 31(2), 95-106.

Creswell, J. W. (1994). Research design: Qualitative \& quantitative approaches: Sage Publications, Inc.

Cuizon, G. (2009). The measurable effects of sales promotions in strategic business planning. Retrieved June, $27,2015$.

Das, P. R. (1992). Semantic cues and buyer evaluation of promotional communication. American Marketing Association Educator's Proceedings: Enhancing Knowledge Development in Marketing, 12-17.

Gilbert, D. \& Jackaria, N. (2002). The efficacy of sales promotions in UK supermarkets: a consumer view. International Journal of Retail \& Distribution Management, 30(6), 315-322.

Kim, Y. K. (2002). Consumer value: an application to mall and Internet shopping. International Journal of Retail \& Distribution Management, 30(12), 595-602.

MOULAND, W. (2002). Hitting your target with direct mail coupons. MARKETING, 107(22), 19.

Nachmias, C. \& Nachmias, D. (1996). Research designs: cross-sectional and quasi-experimental designs. Research methods in the social sciences, 125-151.

Neslin, S. A. (2013). Academic Positions. Marketing science, 31(2), 216-235.

Park, E. J., Kim, E. Y., Funches, V. M. \& Foxx, W. (2012). Apparel product attributes, web browsing, and eimpulse buying on shopping websites. Journal of Business research, 65(11), 1583-1589.

Sinha, I. \& Smith, M. F. (2000). Consumers' perceptions of promotional framing of price. Psychology \& Marketing, 17(3), 257-275.

Thota, S. C., Song, J. H. \& Larsen, V. (2010). Do animated banner ads hurt websites? The moderating roles of website loyalty and need for cognition. Academy of Marketing Studies Journal, 14(1), 91.

Totten, J. C. \& Block, M. P. (1994). Analyzing sales promotion: text \& cases: how to profit from the new power of promotion marketing: The Dartnell Corporation.

Yoon Kin Tong, D., Piew Lai, K. \& Fa Tong, X. (2012). Ladies' purchase intention during retail shoes sales promotions. International Journal of Retail \& Distribution Management, 40(2), 90-108. 